\section{International Scientific Journal Theoretical \& Applied Science}

Kozimkhon Kaxramonovich Sagdullaev doctoral candidate-researcher of State institute of arts and culture of Uzbekistan, Uzbekistan mirzokozimxon@gmail.com

p-ISSN: 2308-4944 (print) e-ISSN: 2409-0085 (online)

mitekozimxon

Published: $30.07 .2015 \quad \underline{\text { http://T-Science.org }}$

SECTION 16. Music. Cinema art. Theatre.

\title{
THEATRICAL JOURNALISM TODAY: ISSUES OF IDENTITY
}

Abstract: This article is an attempt of terminological understanding of theatrical journalism as an independent sphere of active work with their tasks, methods of presentation, as well as communication functions and use of related skills.

Key words: theatrical journalism, theater critic, theater science, arts criticism, communicator, identifying features, art's Journalism, media space, mediaworld.

Language: Russian

Citation: Sagdullaev KK (2015) THEATRICAL JOURNALISM TODAY: ISSUES OF IDENTITY. ISJ Theoretical \& Applied Science 07 (27): 147-150.

Soi: http://s-o-i.org/1.1/TAS-07-27-26 Doi: crossef http://dx.doi.org/10.15863/TAS.2015.07.27.26

\section{ТЕАТРАЛЬНАЯ ЖУРНАЛИСТИКА СЕГОДНЯ: ВОПРОСЫ ИДЕНТИЧНОСТИ}

Аннотация: Настоящая статья представляет собой попытку терминологического осмысления театральной журналистики как самостоятельной сферы активной деятельности со своими задачами, методами подачи материала, а также коммуникаторскими функциями и использованием опыта смежных специиальностей.

Ключевые слова: театральная журналистика, театральная критика, театральная публицистика, театроведение, искусствоведение, коммуникатор, идентифицирующие признаки, арт-журналистика, медиа пространство, медиа мир.

Театральная журналистика - движущая сила коммуникативной системы «Сценическое искусство и СМИ» [4], отданная продолжительное время власти журналистики и театроведения (несмотря на свой опыт и мировое признание), уже давно нуждается в закреплении за ней собственного статуса как самостоятельной единицы с четко изложенными, дифференцированными функциями и терминологическими уточнениями.

Ответить на эти вопросы мешали, вероятно, разные причины, в числе которых структура театральной журналистики, состоящая из различных смежных профессиональных сфер деятельности, включая в искусствоведение, историю и теорию театра, социологию, культурологию, филологию, литературнохудожественную критику, психологию художественного творчества. Потому не без основания в одном случае театральная журналистика воспринималась исключительно в рамках критики, в другом, критика рассматривалась как составная часть журналистики (А.Баканурский, Н.Агафонова) [1, 2], в третьем - критика и журналистика противопоставлялись друг другу в качестве антитезы (В.Собиянский) [7] и т.д.

Как полагает А.Баканурский, театральная журналистика представляет собой «систему жанров, объединенных одной театральной тематикой» [2, С. 96], где есть место и театральной критике и театральной публицистике. И с данной установкой сложно спорить, поскольку она справедливо отражает суть вещей, не приуменьшая их значение, как в качестве самостоятельных профессий, так и в качестве важнейших составляющих именно театральной журналистики. Объединяющим началом во всех этих случаях служит коммуникатор, то есть журналист, обладающий художественно-критическим, публицистским, аналитическим дарованием и личностными качествами лидера, организатора и т.д.

Таким образом, идентифицирующие признаки театральной журналистики - в ее самостоятельности, самодостаточности как 
сферы активного действия, способности решать собственные задачи собственными технологическими, методологическими приемами, используя также инструменты журналистской, театроведческой деятельности, сопредельных отраслей культуры и науки.

Можно говорить о преимуществах театральной журналистики в плане широкого охвата художественных реалий, осуществляемых не только в замкнутом пространстве театральной сцены, но и на большой площади, на радио, телевидении, в печати и интернете. Можно также говорить о ее коммуникативных возможностях и способности охватить одновременно разные в возрастном, социальном, профессиональном отношениях слои населения, использовать новые функциональные мощности, имеющие отношение и к театральной критике, и к публицистике, и к искусствоведению, которое уже давно интегрировалось с другими общественно-гуманитарными науками.

Именно театральная журналистика, наряду с другими печатными изданиями, способствовала развитию критической мысли во всех аспектах. Если письменная ее форма существует в рамках печатных изданий, интернета, то изустная составляет важнейший сегмент радио, телевидения, что характерно и для критики, и для публицистики. Рецензия, творческий портрет тоже являются жанрами и театральной критики и аналитической (рациональной) публицистики, что еще раз говорит в пользу того, что театральная журналистика делает общее с ними дело, базируясь на собственных приоритетах.

Многие специалисты в разное время пытались разобраться в специфике газетножурнальных материалов, посвященных театру. В их числе и небезызвестный Шарль-Огюстен Сент-Бёв, который делит критику на два рода. Одна - «рассудительная, сдержанная, более узкая по своей теме..., разъясняет прошлое, классифицируя и располагая в определенном порядке имена и факты». «Критика другого рода», т.е. журналистика - это есть представление о «более разностороннем, гибком, подвижном искусстве, которое развивалось из писем ученых мужей,... перекочевало на страницы газет и стало одним из наиболее действенных орудий современности» [6, С. 167$168]$.

Как считает Л. Саенкова, автор вышеприведенных строк приравнивает по значимости оба рода, подмечая в то же время существующую между ними разницу [5, С. 89].

Однако если в первом случае предполагается «узкая по своей теме», но тщательная по описанию, повествованию, анализу и обобщениям проблематика, сравнительно глубокое проникновение в материал, обстоятельность осмысления художественной реальности, лексическая, композиционная продуманность, то во втором доминирует, эмоциональное высказывание, обусловленное первыми впечатлениями, душевным настроем и имеющее литературную и биографическую ценность.

«Антитеза» возникла в 80-90-е годы XX века (впоследствии процессов застоя) вместе с таблоидной журналистикой. Поверхностная, дилетантская, она своей критической массой начала завоевывать личное пространство в критической среде. И, как утверждает Л. Саенкова, «стала обозначать не столько эстетические подходы, сколько информационные, не столько аналитическую сущность в осмыслении фактов культуры, искусства, сколько рекламно-презентационную» [5, С. 90-91]. Того же мнения придерживается и Дж.Тулок, добавляя к числу функций артжурналистики «продвижение» $[9$,$] .$

Данные суждения дали основание полагать, что театральная журналистика - это вид деятельности, которая аккумулирует в себе критику и журналистику, и условно подразделяется на рекламно-презентационную, базирующуюся на конкретных технологиях, а также на качественную, характеризующуюся аналитическим подходом к материалу.

В нынешней ситуации театральную журналистику следует развивать, не оставляя ее на репортерском уровне, осваивать также современные подходы и передовые технологии в этой области, изучать мировой опыт, овладевая ее достижениями, теорией и креативной практикой.

Журналист, освещающий сценическое искусство, одновременно выполняет функции коммуникатора - связующего звена между театром и публикой (социумом), театром и критикой, критикой и публикой, способствуя возникновению коммуникационной системы: театр - критика - публика, являясь фактором массового воздействия на аудиторию (читателя, слушателя, зрителя).

Простой потребитель принимает информацию так, как она есть (прямо, непосредственно), в то время как образованный человек, владеющий необходимой суммой знаний, аналитическим талантом, мировоззренческими, жизненными позициями, доверяться полностью любой информации не станет и не может в силу собственного интеллектуального и духовного потенциала. Коммуникатору надо очень постараться, чтобы привлечь внимание такого рода подготовленных людей, которые по достоинству оценят его труд или уличат в некомпетентности. 
Как справедливо заметил Сент-Бёв, профессия журналиста требует того, чтобы «опережать публику, управлять общественным мнением, и, если публика заблуждается, сбивается с правильного пути», громко взывать, что «надо возвращаться» [см. Вулф Т.: 3, С.3.].

И когда речь идет о воспитании художественного вкуса, духовной культуры современного общества, то в этом процессе артжурналистика может стать мощным инструментом глокализации в глобализационном процессе (Термин «глокализация» возник на основе объединения терминов «глобализация» и «локализация»; используется в значении сохранения культурного своеобразия в условиях глобализации. Введен в научный обиход в 1995 году Рональдом Робертсоном [см. 8, С.451-453.]).

Потому вопрос подготовки артжурналистов, профессионально освоивших свой предмет, информационные технологии; вопрос выработки механизмов целевого использования кадров (создание условий для работы, обеспечение рабочими местами) всегда актуален с учетом потребительского спроса, который в связи с вводом и активным использованием новых медиа структур только растет изо дня в день.

В мировом медиа пространстве значение арт-журналистики очевидно.

В Германии и ряде других стран она называется журналистикой культуры. В разработанной ЮНЕСКО программе специализированной журналистикой (культура и искусство) [10]. Функционируют также крупные научные центры и общественные организации, занимающиеся мониторингом арт-журналистики (“A national summit on” и др.). Осуществляется и подготовка кадров соответствующего направления.

Большинство зарубежных СМИ располагают отдельными штатными сотрудниками, такими как «театральный обозреватель», «кино обозреватель», «музыкальный журналист», которые существуют в рамках арт-журналистики, свидетельствуя о ее многогранности, многоплановости, многовекторности функционирования и развития, а, главное, о широкой востребованности данной специальности в качестве активного коммуникатора.

Сегодня заметно усиливается и просветительская роль арт-журналистики, которая профессионально освещает творческую жизнь, оказывает влияние на развитие искусства и художественной культуры, оценивает, наблюдает процесс, формируя общественное мнение о произведении, о художнике, о коллективах.

Вместе с тем актуализируются ряд вопросов по развитию и усовершенствованию артжурналистики как неотъемлемой части коммуникативной системы, в которую вовлечен весь мир. Все это в комплексе ставит задачу высокого профессионального мастерства специалистов, воспитания нового поколения журналистов-искусствоведов, хорошо владеющих родным и иностранными языками, современными технологиями подачи материала, ведения диалога, осуществления на высоком профессиональном уровне функций коммуникатора.

Способствуют тому:

- спецкурсы, семинары для артжурналистов с целью обмена опытом, инновационными концепциями, знаниями современных технологий, арт-процессов;

- доскональное владение предметом, широкий кругозор, личностные качества артжурналиста, обеспечивающие высокий статус данной профессии в системе СМИ;

- наличие во всех средствах массовой информации штатной должности «артжурналист»;

- создание секции арт-журналистики в творческих Союзах (театральных деятелей, композиторов, журналистов, художников), или самостоятельным образом.

\section{References:}

1. Agafonova N (2012) Iskusstvovedeniye i xudojestvennaya kritika: $\mathrm{k}$ probleme razgranicheniya polnomochiy // SMI i sovremennaya kulture. Sbornik nauchnix trudov. - Minsk, 2012. - pp. 26-31.

2. Bakanurskiy AG, Ovchinnikova AP (2007) Sovremenniy teatralno-dramaticheskiy slovar. O.: Studiya "Neogotsiant", 2007. - 336 p.
3. Vulf T (2008) Novaya jurnalistika i antologiya novoy jurnalistiki / pod. red. T.Vulfa, E.U.Djonsona. - SPb.: Amfora, 2008. - 576 p.

4. Sagdullayev KK (2013) Teatr i SMI kak kommunikativnaya sistema // Zbiór raportów naukowych. "Teoria i praktyka-znachenie badań naukowych". - Lublin, 2013. - pp. 67-70. 


\begin{tabular}{|c|c|c|c|c|c|c|}
\hline Impact Factor: & $\begin{array}{l}\text { ISRA (India) } \\
\text { ISI (Dubai, UAF } \\
\text { GIF (Australia) } \\
\text { JIF }\end{array}$ & $\begin{array}{l}=1.344 \\
=0.829 \\
=0.356 \\
=1.500\end{array}$ & $\begin{array}{l}\text { SIS (USA) } \\
\text { PИHЦ (Russia) } \\
\text { ESJI (KZ) } \\
\text { SJIF (Morocco) }\end{array}$ & $\begin{array}{l}=0.912 \\
=0.179 \\
=1.042 \\
=2.031\end{array}$ & ICV (Poland) & $=6.630$ \\
\hline
\end{tabular}

5. Sayenkova LP (2009) Literaturnoxudojestvennaya kritika i jurnalistika: istorikokulturniy kontekst // Vesnik BDU. Ser 4. Filalogiya. Jurnalistika. Pedagogika. - Minsk, 2009. - N 1. - pp. 87-91.

6. Sent-Byov SH (1970) Literaturniy portreti. Kriticheskiye ocherki. - Moscow, 1970. - 588 p.

7. Sobiyanskiy VD (2013) Teatralnaya jurnalistika kak ponyatiye i sushnost: ukrainskiy opit // Relga - Moscow, 2013. - N 13. Available: http://www.relga.ru/Environ/WebObjects/tguwww.woa/wa... (Accessed: 12.01.15);
8. (2005) Teoreticheskaya kulturologiya. Moscow: Akademicheskiye proekt; Ekaterinburg: Delovaya kniga, RIK, 2005. $624 \mathrm{p}$.

9. (2015) Podgotovka informatsionnix i inix materialov/Uroven 3: Spetsializirovannaya jurnalistika (iskusstvo i kultura). Predostavleno professorom Djonom Tulokom. - Available: http://rud.exdat.com/docs/index721305.html?page=11 (Accessed: 12.01.15);

10. Spetsializirovannaya jurnalistika (iskusstvo i kultura) Available: http://www.modelcurricula.org/402.p. (Accessed: 10.06.13) 